\title{
Effect of Islamic corporate governance on customer trust: empirical study on Islamic bank
}

\section{Agung Budi Sulistiyo, Siti Maria Wardayati*, Arif Hidayatullah, Shita Silvia Nahdia Riesky}

Faculty of Economics and Business, University of Jember, Jember, Indonesia *Corresponding author: siti.maria@unej.ac.id
Article History

Received, 03 May 2020 Revised 1, 06 May 2020

Revised 2, 24 May 2020 Accepted, 1 June 2020

\begin{abstract}
Purpose: This study aims to analyze the effect of Islamic corporate governance and shariah compliance on customer trust in Islamic bank.

Methodology: The research method used is a quantitative method with random sampling technique. The data analysis technique used is descriptive statistics and multiple linear regression techniques to test the hypothesis.

Findings: The results of the study show that (1) out of the five principles of GCG (transparency, accountability, responsibility, independency and fairness) only transparency has a positive effect on customer trust as indicated by a significance value of 0.047 . (2) shariah compliance has a positive effect on customer trust, besides that shariah compliance is a very large indicator contributing to increase customer trust, indicated by a significance value of 0,000 .

Originality: As far as we are concerned, only a few publications examined the effect of Islamic corporate governance and shariah compliance on customer trust in Islamic bank.
\end{abstract}

Keyword: Islamic corporate governance, shariah compliance, trust.

Cite this:

Sulistiyo, Agung Budi, et al. (2020). Effect of Islamic corporate governance: mpirical study on Islamic bank. Asian Joumal of Islamic Management, 1(2), 12-24. DOI: 10.1108/AJIM.vol2.iss1.art2

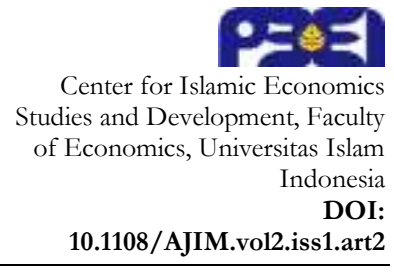

\section{Introduction}

The level of return on assets shows the ability of bank management to generate income from the use of assets owned. Islamic bank assets are usually utilized in the form of financing. Funding is widely offered by bank management in the form of financing for sale and purchase with murabaha, istishna and salam schemes. The other financing are in the form of profit sharing in the form of mudharabah, musyarakah and mudharabah. Apart from Islamic bank financing, there is also a source of income from SBIS, secondary markets and bank services. While external factors that affect income include inflation, interest rates and exchange rates.

Previous studies have shown the role of inflation, interest rates and exchange rates, including the research conducted by Masood. B and Ashraf. M (2012) empirically investigates the impact of macroeconomic and bank specific variables on the profitability of Islamic banks. Research variables include bank internal factors such as asset quality, asset size, liquidity, deposits, gearing operating efficiency ratios. In addition to that, it includes macroeconomic variables such as real GDP growth rates and annual inflation. The result shows that efficient management in the impact of their operating costs was significantly positive on the profitability of Islamic banks. 
Sudarsono (2017) examines the factors that influence the profitability (ROA) of Islamic banking in Indonesia. The data used monthly data from Islamic bank financial statements for the period 20102015. The results of the data processing show that FIN and BOPO are positively related to ROA, while DPK, TBH, FDR have a negative relationship with ROA. Additionally, SBIS and NPF have no effect on ROA. On the other hand, financing responses to shocks that occur in ROA, FIN, FDR, NPF and BOPO are responded positively by ROA. While the ROA response to shocks that occur in FDR, SBIS and TBH is negative.

Idris et. al (2011) investigated the profitability of Islamic banks in Malaysia by including several internal factors such as liquidity, credit risk of bank size, capital adequacy, and expenditure. The results showed that only the size of the bank is a significant and positive determinant of the profitability of Islamic banks.

Ubaidilah (2016) examines the effects of Capital Adequacy Ratio (CAR), Financing to Deposit Ratio (FDR), Non Performing Financing (NPF), Preparation of Eliminating Earning Assets (PPAP), Operational Costs per Operating Income (BOPO), Share of Financing, Bank Indonesia Sharia Certificate (SBIS). The results of this study indicate that the NPF, PPAP, and SBIS variables do not show a significant effect on profitability. The FDR variable shows a significant positive effect on profitability, while the CAR, BOPO, and Financing Share variables have a negative and significant effect on profitability.

Grassa (2012) examines the relationship between risk and income structure of Islamic banks from GCC countries by using data from 42 Islamic banks during period of 2002-2008. The results show that registered and unregistered Islamic banks are associated with higher insolvency risk and greater risk for profit sharing products and loss of trust. This study did not find a relationship between the level of risk and non-profit operating income sharing losses, therefore the registered banks prefer to invest in non-profit-sharing products in contrast to profit-and-loss-sharing products.

Wasiuzzaman, A. and Gunasegavan, U.N. (2013) conducted a comparative study on the performance of 14 conventional and Islamic banks in Malaysia during the period of 2005 to 2009 . They have used multiple regression analysis and independent sample t-test. The findings show that returns to bank size, average assets and board size of non-Islamic banks are greater than those of Islamic banks. The study also found significant comparisons between other variables from research in Islamic and non-Islamic banks except for board independence and profitability.

Ali et.al (2011) empirically investigated the relationship between macroeconomic indicators and bank specific variables on profitability in Pakistani commercial banks using data during the period from 2006 to 2009. The results of the study suggest that a good economic environment and efficient management in the asset side has a significant impact on profitability. On the other hand, lower profitability is found in high credit risk and capitalization. It was concluded that the higher the operating efficiency, the higher the profitability.

Cevik, S. and Charap, J. (2015) examined returns on Islamic and conventional bank deposits in Indonesia, Turkey, and Malaysia. Research findings suggest that there is a long-term integration between PLS returns and conventional bank deposit rates. However, it was also found that conventional bank deposit rates cause a return on PLS accounts.

Ahokpossi, C. (2013), empirically investigated the determinants of bank interest margins in the Sub-Saharan African countries by using unbalanced panel data from 41 SSA countries with 456 banks over the period 1995 to 2008 . They have applied a random effects model. The findings suggest that bank specific factors (bank equity, liquidity risk and credit risk) are the main determinants of interest margins. On the other hand, interest margin and inflation are sensitive to each other. This sensitivity is not for economic and public growth, but for foreign ownership.

\section{Literature Review and Hypotheses Development}

\section{Agency Theory}

Agency theory states that an organization that employs agents to work on its behalf, and the reason why employees do not always perform as expected by the employer is because the 
interests of workers and employers are not in perfect alignment. According to Jensen and Meckling (1976) this agency theory studies agency relationships that occur when one or more principals employ other people (agents) to provide a service and delegate authority for decisionmaking to the agent.

According to Eisenhard (1989), agency theory is based on three assumptions, namely: (a) assumptions about the models of man, (b) assumptions about organization, (c) assumptions about information. Assumptions about human nature explain that humans have self interest, bounded rationality and risk aversion. Organizational assumptions are the existence of conflict between members in the organization, efficiency as a criterion for productivity and the existence of asymmetric information between principals and agents. The latter is the assumption about information explaining that information is something that is for sale (Hanggareni, 2015).

Principals as capital owners have the right to have access about company internal information. While agents have information about the company's operations and performance in a real and comprehensive manner because the agent's own task is to carry out operational activities within the company. However, agents do not have the right to make decisions, especially strategic, long-term and global decisions. Principals and agents conflict with each other, where agents as providers of information and principals as decision-makers will sometimes cause conflicts, but principals and agents need each other. The difference in interests between principals and agents is commonly called the agency problem.

Agency problems are usually caused by asymmetric information, that is, information that is out of balance because the information conveyed is not the same to the principal and agent. As a result of the imbalance of information, it creates two problems caused by the principal's difficulty in controlling and also monitoring the actions of its agents. The two problems are: (1) Moral hazard, namely problems arising from the agent not implementing the agreement that was taken at the time of the employment contract, and (2) Adverse selection, namely the problem where the principal does not know whether the decision taken by the agent is in accordance with the correct information or negligence occurs in the task (Jensen and Meckling, 1976).

The existence of Agency Problems can lead to agency costs, which consist of: (1) monitoring costs, these costs are issued by principals to monitor agents, and also efforts to control agent behavior through budget restriction, and compensation policies; (2) Bonding costs, these costs are issued by the agent as a guarantee that the agent does not use certain actions that harm the principal or as a guarantee that the principal will be compensated if he does not take many actions; (3) Residual loss, the cost of reducing the level of welfare of principals and agents after an agency relationship (Jensen and Meckling, 1976).

Corporate governance is a concept based on agency theory which is expected to be useful as a tool to provide investors with confidence that they will receive a return on the funds they invest. This concept is related to giving investors the confidence that the board of directors and managers (management) will give them a profit, confident that management will not steal and also embezzle or invest in unfavorable projects related to the funds/capital that have been invested by investors, and relating to how investors control the management (Sheileifer and Vishny, 1999). Corporate governance can also function to emphasize or reduce agency costs.

\section{Stewardship Theory}

According to Donaldson and Davis (1997), stewardship theory is considered as an alternative to corporate governance theory or theory that explains the relationship between owners (shareholders) and management. Stewardship theory is a more recent theory compared to agency theory (Donaldson, 1990) originating from organizational theory that specializes in psychology and sociology (Donaldson, 1990; Donaldson and Davis, 1997), both theories together discussing problems governance of the mandate given by the principal to the agent. But these two things have many differences in terms of the assumption of the models of man, especially regarding the agents used. 
According to Donaldson and Davis (1997), Stewardship theory is based on three assumptions of models of man, namely: collectivistic, pro-organizational, and trustworthy. Stewardship theory emphasizes that models of man is based on the assumption that managers will make decisions in the best interest of the organization, can put the choice of behavior collectively (collectivist) above the choice of self-serving so that in stewardship the main characteristic is cooperation between all members organization.

\section{Good Corporate Governance}

Good Corporate Governance arises in relation to principal agency theory, which is to avoid conflicts between the principal and its agents. Conflicts arise because of differences in interests must be managed properly so it will not harm the parties involved (Hamdani, 2016). GCG has been widely practiced in international companies. In fact, every company listed on the stock exchange or companies that get funds from outside, in general, maintain good governance. Usually when a company does a rating, one of the things measured is the GCG practices.

Indonesia also formed the National Committee on Corporate Governance Policy (KNKCG). Since 2011 this committee has issued a code of best practice that is voluntary compliance, and is utilized as a reference for implementing GCG for companies in Indonesia. The Forum for Corporate in Indonesia (FGCI) defines corporate governance as a set of rules governing the relationship between holders, management (managers) of the company, investors, creditors, government, employees, as well as other internal and external stakeholders related to rights and their obligations or in other words a system that controls the company. The purpose of corporate governance is to create added value for all stakeholders.

Good corporate governance practices, theoretically, can increase value (valuation) for companies by increasing the company's financial performance, reducing the risk that may be done by decisions that benefit themselves, and in general corporate governance can increase investor confidence. A survey conducted by McKinsey \& Co explains that corporate governance is the main concern of investors to match financial performance and growth potential, especially for emerging markets.

\section{Shariah Enterprise Theory (SET)}

Shariah Enterprise Theory (SET) is an entrepreneurial theory that has been internalized with Islamic values with the aim of producing a more humane and transcendental theory. Enterprise theory according to Triyuwono is a theory that acknowledges accountability not only to the owner of the company, but to a wider stakeholder group. Enterprise theory is able to accommodate the plurality of society, that is because the concept of enterprise theory shows that economic power is no longer in one hand (enterprise theory), but is in many hands (stakeholders) (Triyuwono, 2007).

According to experts, enterprise theory is more appropriate for an economic system that is based on shariah values. This is because enterprise theory emphasizes broader accountability. The concept of shariah itself prohibits the circulation of wealth only in certain circles. However, enterprise theory needs to be developed further to have a form that is closer to shariah. The development was carried out in such a way that finally obtained a form of theory known as Shariah Enterprise Theory (SET) (Triyuwono, 2007).

Shariah Enterprise Theory (SET) does not only care about the interests of individuals (shareholders), but also other parties. Therefore, SET has a great concern for broad stakeholders. According to SET stakeholders include Allah, humans and nature. Allah is the highest and the sole purpose of human life (Triyuwono, 2007).

The second stakeholders of the SET theory are those who directly contribute to the company (Direct-stakeholders) both financial and non-financial contributions and those who do not contribute to the company (indirect-stakeholders), but according to Sharia principle they are parties who have the right to obtain welfare from the company. 
The third stakeholder of SET is nature. Nature is a party that contributes to the life and death of the company as part of Allah and humans. The company exists physically because it is founded on the earth, uses energy spread inside, produces using raw materials from nature, and provides services to other parties using energy available in nature and others (Sari, 2017).

\section{The influence of transparency on customer trust}

Transparency according to Bank Indonesia Regulation (PBI) Number 11/33/PBI/2019 is transparency in providing material and relevant information and transparency in the process for making a decision. For the activities of Islamic banks to run objectively, professionally and protect the interests of stakeholders, transparency principles are needed. Transparency is a principle that guarantees access or freedom for everyone to obtain information about the administration of the government, which includes policy, making process and the results achieved. According to Government Regulation Number 101 Year 2000, transparency can create mutual trust between government and society through information providers and ensure the ease of obtaining accurate and adequate information. Transparency is the disclosure of important information for all interested parties to know exactly what happens and has happened. The benefit of the application of the principle of transparency is that stakeholders can understand the risks that may occur in conducting transactions in the company. Research conducted by Nurohmah (2013) states that transparency has a significant effect on the trust of bank customers. Other research conducted by Yuraida (2016) states that transparency has a moderate effect on customer confidence, so that the effect is very small. This shows that this variable only slightly affects customers to trust BPD DIY Syariah, while transparency does not affect the reputation of BPD DIY Syariah at all.

H1: transparency affects customer trust.

\section{Effect of accountability on customer trust}

Accountability according to Bank Indonesia Regulation (PBI) Number 11/33/PBI/2019 is the clarity of the functions and implementation of the accountability of bank organs so that management is run effectively. Accountability is a prerequisite needed to achieve a sustainable performance of Islamic bank business. Nurohmah (2012) explains that accountability is an obligation to answer and explain the performance and actions of the leadership of the organization to those who have the right or authority to request the information. Through this principle, the decision-making process or performance can be monitored, assessed and criticized. With the existence of this principle, the financial statements presented have been informed with full responsibility. Reporting disclosed with full responsibility will give confidence to investors. If there is a misinformation, there will be a party responsible for the misinformation. Research conducted by Nurohmah (2012) states that accountability has a significant effect on the trust of customers of Bank Muamalat Kendal. While a different study was found by Yuraida (2016) which states that accountability does not affect the trust of BPD DIY Syariah customers.

H2: accountability affects customer trust.

\section{Effect of responsibility on customer trust}

Responsibility according to Bank Indonesia Regulation (PBI) Number 11/33/PBI/2019 is the suitability of bank management with the applicable laws and regulations and the principles of healthy bank management. These principles are needed so that Islamic banks can guarantee longterm business sustainability. According to Juliansyah (2014) in carrying out business continuity, banks must adhere to the principle of prudence and guarantee the implementation of applicable regulations. Responsibility is the active involvement of each of the organization's actors and interested parties in supporting the increase in organizational value. The intended involvement is the fulfillment of responsibilities, rights, and authority as well as appropriate actions taken in 
accordance with his position. Research conducted by Nurohmah (2012) states that responsibility has a significant effect on the trust of customers of Bank Muamalat Kendal. While a different study was found by Yuraida (2016) which states that responsibility does not affect the trust of BPD DIY Syariah customers.

H3: responsibility influences customer trust.

\section{The effect of independence on customer confidence}

Independence according to Bank Indonesia Regulation (PBI) Number 11/33/PBI/2019 is competent, capable of acting objectively and free from influence or pressure from any party (independent) and has a high commitment to develop Islamic banks. So that each organ does not dominate each other and cannot be intervened by other parties, the Islamic bank must be managed independently. The principle of independence is an action whereby Islamic banks must be able to avoid conflicting interests from stakeholders, a conflict of interest is a state of conflict between the interests of the company and personal interests. Independency is a condition where the management of a company is carried out professionally without any conflict of interest and influence from the management that is not in accordance with the applicable laws and regulations and enforces healthy corporate principles (Wahananto, 2009). Research conducted by Nurohmah (2012) states that independence significantly influences the trust of customers of Bank Muamalat Kendal. While a different study was found by Yuraida (2016) which states that independence does not affect the trust of BPD DIY Syariah customers.

H4: independence influences customer trust.

\section{Effect of fairness on customer trust}

Fairness according to the National Committee on Governance Policy (KNKG) as stipulated in the General Guidelines of GCG in Indonesia is fairness and equality in fulfilling the rights of stakeholders arising based on agreements and applicable laws and regulations. In this case, Islamic banks must pay attention to the interests of shareholders and other stakeholders based on the principle of fairness and equality. Fairness relates to justice for all stakeholders and all transactions relating to interested parties. Fairness shows the existence of equal treatment to all interested parties (stakeholders) in accordance with the criteria and the proper portion. Research conducted by Nurohmah (2012) states that fairness has a significant effect on the trust of customers of Bank Muamalat Kendal. The research is in line with research conducted by Yuraida (2016) which states that fairness influences the trust of BPD DIY Syariah customers.

H5: fairness affects customer confidence.

\section{The effect of shariah compliance on customer trust}

In its operational activities, Islamic banks must apply Islamic principles. This necessity is motivated by the desire of Muslims for a bank that is based on Islamic principles (Faozan, 2014). The Law on Shariah Banking Number 21 Year 2008 explains that the principle of shariah in shariah banking is the principle of Islamic law in banking activities based on the fatwa issued by DSN-MUI. Thus, shariah compliance is a form of compliance of shariah banks in fulfilling shariah principles in their operational activities. The application of shariah compliance in shariah banking can be said to have been fulfilled if all of its businesses do not contain usury, gharar, gambling, run business on halal profit, carry out the trust entrusted by the customer and manage zakat, infaq and alms according to shariah regulations. Research conducted by Chapra and Ahmad shows that 288 customers $(62 \%)$ of the 463 other customers involved in the GCG survey were conducted on 14 Islamic banks in Bahrain, Bangladesh and Sudan said they would transfer their funds to other Islamic banks if there were shariah violations in their operations. Junusi (2013) shariah compliance is the compliance of Islamic banks to the principles of Islamic shariah, especially concerning procedures for doing muamalah in accordance with Islam. Increasing shariah 
compliance towards banks will increase customer confidence in banks. Wardayati (2011) conducted a study with the results that the implementation of shariah compliance is an influential indicator in the implementation of shariah governance. Shariah governance in this study was developed from the concepts of Good Corporate Governance and shariah compliance. Another study conducted by Yuraida (2016) states that shariah compliance is a differentiator from GCG in conventional banks and Islamic banks. Shariah compliance significantly affects the reputation and trust of DIY Syariah BPD customers.

H6: Shariah compliance affects customer trust.

\section{Methods}

\section{Type of Research and Data Collection}

This research belongs to explanatory research using quantitative approach. This study uses primary data, the data obtained from the activities of distributing questionnaires and direct interviews with customers. The population in this study were all employees and customers of Bank Syariah Mandiri Situbondo Brach Office. The sample selection method used in this study was a random sampling method with 100 respondents.

Customer trust as an independent variable can be measured by these indicators, namely (1) past experience (2) good and actual information. Transparency is an open, timely, clear and comparable information (Hanggraeni, 2015). Transparency can be measured by these indicators namely (1) open information (2) timely information (3) clear and relevant information (4) comparable information (Nurohmah, 2012). Accountability is the role and responsibility and business support to ensure the balance of the interests of management and shareholders (Hanggraeni, 2015). Accountability can be measured by these indicators namely (1) clarity of function (2) responsibility for roles (3) assessment in performance and decision-making (Nurohmah, 2012). Responsibility is the obligation of an entity to ensure compliance with applicable rules and regulations (Hanggraeni, 2015). Responsibility can be measured by these indicators namley (1) compliance to regulations (2) caution and implementing applicable provisions in accordance with social values (3) caring for the surrounding environment (Nurohmah, 2012). Independency is a guarantee of supervisors, directors and management to carry out their authority and responsibilities independently (Hanggraeni, 2015). Independence can be measured by indicators of (1) professional management and responsibility (2) independent without interference from other parties (Nurohmah, 2012). Fairness is a guarantee for the protection of the rights of shareholders and to guarantee the implementation of commitments with investors (Hanggraeni, 2015). It can be measured by indicators of (1) equity of shareholder rights (2) fairness for customers (3) equality (Nurohmah, 2012). Shariah compliance is an obligation of an Islamic bank in fulfilling its compliance to sharia principles. Shariah compliance can be measured by indicators of (1) bank compliance in carrying out its operational activities (2) getting halal profit (Faozan, 2014).

\section{Data Analysis Method}

This study uses a descriptive statistical approach. Descriptive statistics are statistics used to analyze data by describing data that has been collected without any intention to make general conclusions (Sugiyono, 2017). Validity shows the degree of accuracy between the data that actually occurs on the object with data collected by researchers (Sugiyono, 2017). Reliability test shows the extent of the results of measurements using the same object, will produce the same data (Sugiyono, 2017). Normality test aims to know whether in the regression model the dependent variable and the independent variable have an influence or not (Ghozali, 2016). Normality test is needed to test other variables by assuming that the residual value follows the normal distribution. Data is said to be normal when it is following diagonal lines. Heteroscedasticity test aims to test whether in the regression model there is an inequality of variance from the residuals of one observation to another observation. A good regression model is when homoscedasticity or heteroscedasticity does not 
occur (Ghozali, 2106). The way to detect the presence of heteroscedaticity can be done by the glacier test with the condition that if sig $>0.05$ then there are no symptoms of heteroscedasticity. Autocorrelation arises due to consecutive observations are related to one another (Ghozali, 2016). A good regression model is a regression model that is free from autocorrelation. The autocorrelation test used in this study is the Durbin-Watson (DW) test. Regression is considered free of autocorrelation if the value is higher than Durbin Upper (DU) and less than Durbin Lower (DL). It can be formulated by DU $<$ DW $<4$-DU. Multicollinearity test aims to determine whether relationship between independent variables exist or not (Ghozali, 2016). A good regression model should not raise correlation between independent variables. This study uses the VIF (Variance Inflation Factor) test with the condition that if the tolerance number is above 0.1 and VIF $<10$ it means that symptoms of multicollinearity does not exist. This study uses multiple linear regression analysis with the regression equation model as follows:

$\mathrm{Y}=\alpha+\mathrm{b} 1 \mathrm{X} 1+\mathrm{b} 2 \mathrm{X} 2+\mathrm{b} 3 \mathrm{X} 3+\mathrm{b} 4 \mathrm{X} 4+\mathrm{b} 5 \mathrm{X} 5+\mathrm{b} 6 \mathrm{X} 6+\mathrm{e}$

Explanation: $\mathrm{Y}=$ Bank Mandiri Customer Trust customer trust; $\alpha=$ Constants; b1b2b3b4b5b6 = Regression Coefficient; $\mathrm{X} 1=$ Transparency; $\mathrm{X} 2=$ Accountability; $\mathrm{X} 3=$ Responsibility; $\mathrm{X} 4=$ Independency; X5 = Fairness; X6 = Shariah Compliance

\section{Results and Discussions}

100 respondents obtained were used as research samples. Descriptive statistical analysis in this study includes the Minimum Value, Maximum Value, Mean and Standard Deviation (Std). The following are the results of a descriptive analysis test using SPSS.

Table2. Descriptive Analysis Test

\begin{tabular}{lccccc}
\hline Model & $\mathrm{N}$ & Min & Max & Mean & Std. Dev \\
\hline Transparency & 100 & 9 & 15 & 12.48 & 1.18 \\
Accountability & 100 & 10 & 15 & 12.62 & 1.16 \\
Responsibility & 100 & 9 & 15 & 12.19 & 0.9 \\
Independency & 100 & 9 & 15 & 12.88 & 1.29 \\
Fairness & 100 & 9 & 15 & 13.01 & 1.32 \\
Shariah Compliance & 100 & 8 & 15 & 12.86 & 1.39 \\
Customer Trust & 100 & 8 & 15 & 12.84 & 1.43 \\
\hline Valid N(listwise) & 100 & & & & \\
\hline
\end{tabular}

Source: Primary data processed, 2018

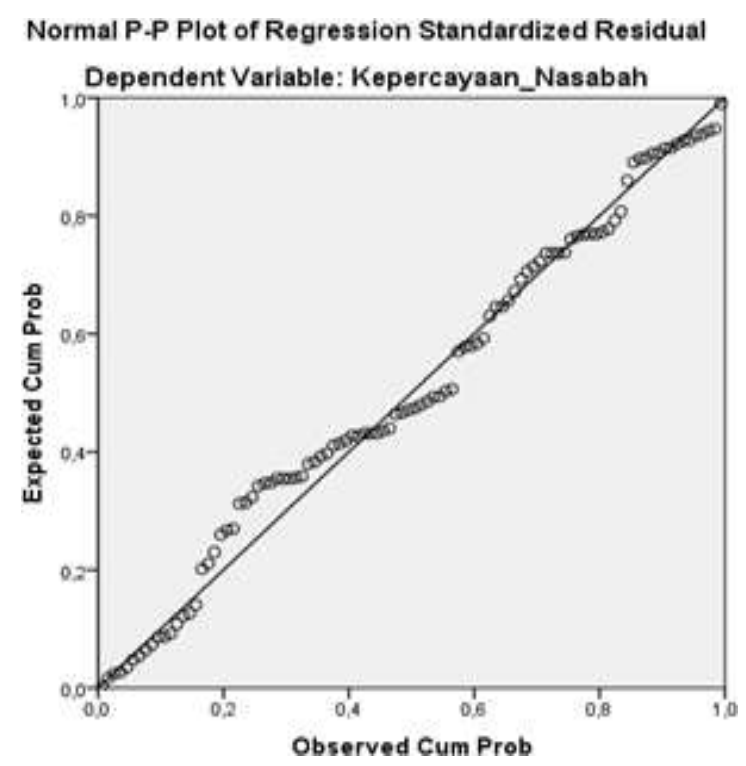

Figure 2. Normality Test 
Based on the results in Figure 2, the data are normally distributed based on the graph that shows that the points follow and approach the diagonal line. It can be concluded that the regression model meets the normality assumption.

Table 3. Heteroscedasticity Test

\begin{tabular}{lcll}
\hline \multicolumn{1}{c}{ Variable } & T & Sig & Explanation \\
\hline Transparency & 0,466 & 0.64 & Heteroscedasticity does not occur \\
Accountability & $-0,976$ & 0,332 & Heteroscedasticity does not occur \\
Responsibility & $-0,45$ & 0,654 & Heteroscedasticity does not occur \\
Independency & 0,678 & 0,946 & Heteroscedasticity does not occur \\
Fairness & $-0,538$ & 0,592 & Heteroscedasticity does not occur \\
Shariah Compliance & 1,182 & 0,24 & Heteroscedasticity does not occur \\
\hline
\end{tabular}

Source: Primary data processed, 2018

To detect the presence of heteroscedasticity is done with glacier test. If sig. $>0.05$, it means that there are no symptoms of heteroscedasticity and it indicates a good model. Based on the results of Table 4.6.2, the level of significance exceeds 0.05 , meaning that all data is fulfilled and there are no symptoms of heteroscedasticity.

Table 4. Autocorrelation Test

\begin{tabular}{cccccc}
\hline Model & $\mathrm{R}$ & $\mathrm{R}$ Square & Adj. R Square & Std. Error of the estimate & Durbin- Watson \\
\hline 1 & 0.66 & 0.44 & 0.4 & 1.1 & 2.28 \\
\hline
\end{tabular}

Source: Primary data processed, 2018

Based on table 4 , the result is $1.5496<2.283>1.8031$. It can be concluded that the data contained no autocorrelation and the autocorrelation test was fulfilled.

Table 5. Multicollinearity Test

\begin{tabular}{lccl}
\hline \multicolumn{1}{c}{ Variables } & Tolerance & VIF & Explanation \\
\hline Transparency & 0,601 & 1,663 & Multicollinearity does not occur \\
Accountability & 0,658 & 1,521 & Multicollinearity does not occur \\
Responsibility & 0,748 & 1,337 & Multicollinearity does not occur \\
Independency & 0,638 & 1,465 & Multicollinearity does not occur \\
Fairness & 0,677 & 1,477 & Multicollinearity does not occur \\
Shariah Compliance & 0,732 & 1,367 & Multicollinearity does not occur \\
\hline
\end{tabular}

Source: Primary data processed, 2018

Based on the results in table 5, it shows that all tolerance numbers above 0.1 and VIF are less than the value of 10. It can be concluded that the data contained no symptoms of multicollinearity and the multicollinearity test was fulfilled.

Based on the results of the partial significance test (t-test) listed in table 6 shows that accountability has a $t$ value and a significance level of $-0,416$ and 0.678 . T count value of - 0,416 is smaller than 1.985 ( $\mathrm{t}$ count $<\mathrm{t}$ table) and a significance value of 0.678 is higher than 0.05 . It can be concluded that the accountability variable does not affect customer trust. The result of this study supports Yuraida (2016) which states that accountability has no effect on customer confidence in BPD DIY Syariah. Another factor that may influence the insignificance of the accountability variable on customer trust is that the customer only pays attention to the services provided by each Islamic bank unit and is also suspected due to the lack of customer knowledge regarding the importance of policy information taken by Islamic banks (Purnamasari and Darma, 2015 ). 
Based on the results of the partial significance test ( $\mathrm{t}$ test) contained in table 6 , it shows that responsibility has a calculated $t$ value and a significance level of 1.941 and 0.055 . $T$ value of 1.941 is smaller than 1.985 ( $\mathrm{t}$ count $<\mathrm{t}$ table) and a significance value of 0.678 is higher than 0.05 . It is concluded that the responsibility variable does not affect customer trust. This study is in line Yuraida (2016) which states that the responsibility variable does not affect customer confidence in BPD DIY Syariah. Another factor that cause the inability of variable responsibility to influence is the lack of customer knowledge regarding the laws and regulations concerning Islamic banks. In addition, it is suspected that the lack of bank socialization to customers related to sharia banks' concern for the community and the environment (Purnamasari and Darma, 2015).

Table 6. Significance Test Results (t Test)

\begin{tabular}{llcl}
\hline \multicolumn{1}{c}{ Variable } & t value & Sig & Explanation \\
\hline Transparency & 0,466 & 0,642 & Has an effect \\
Accountability & $-0,976$ & 0,332 & Has no effect \\
Responsibility & $-0,45$ & 0,654 & Has no effect \\
Independency & 0,678 & 0,946 & Has no effect \\
Fairness & $-0,538$ & 0,592 & Has no effect \\
Shariab Compliance & 1,182 & 0,24 & Has an effect \\
\hline
\end{tabular}

Source: Primary data processed, 2018

Based on the results of the partial significance test ( $t$ test) contained in table 6 . it shows that responsibility has a calculated value and a significance level of 0.357 and 0.722 . $T$ value of 0.357 is smaller than 1.985 ( $\mathrm{t}$ count $<\mathrm{t}$ table) and a significance value of 0.722 is higher than 0.05 . It is concluded that the independency variable does not affect customer trust. This study is in line with Yuraida (2016) which states that the independency variable does not affect customer confidence in BPD DIY Syariah. Another factor that cause the lack of independency influence is the level of customer trust on Islamic bank performance having the authority to regulate and control them. This research supports Yuraida (2016) which states that independence does not affect BPD DIY Syariah trust.

Based on the results of the partial significance test ( $t$ test) contained in table 6 it shows that fairness has a calculated value and a significance level of 1.081 and 0.282 . $T$ value of 1.081 is smaller than 1.985 ( $\mathrm{t}$ arithmetic $<\mathrm{t}$ table) and a significance value of 0.282 is greater than 0.05 . It is concluded that the variable of fairness does not affect customer trust. The research contradicts Nurohmah's (2013) which states that the fairness variable influences customer trust in Muamalat Bank of Kendal. Another factor that causes the ineffectiveness of fairness variable is the lack of opportunities given by Islamic banks to customers to provide suggestion or critics and follow up on customer complaints. Fairness contains an element of fair treatment and equal opportunity in accordance with its portion. So in this case, it is important for banks to treat their customers fairly as possible without discriminating between one customer and another customer.

Based on the results of the partial significance test (t test) contained in table 6 it shows that fairness has a calculated $t$ value and a significance level of 4.562 and 0,000 . T value of 4.562 is greater than 1.985 (tcount $<\mathrm{t}$ table) and a significance value of 0.000 is less than 0.05 . It can be concluded that the shariah compliance variable influences customer trust. This study is in line with Wardayati (2011) which states that shariah compliance affects the reputation and trust of customers at Bank Muamalat Indonesia in Central Java. Shariah compliance is an indicator having high contribution in increasing customer trust, so that Islamic banks must be careful in carrying out their operational activities in accordance with the existing rules of Islamic banks as well as being obedient to the Islamic provisions, it is due to Islamic banks are financial institutions that operate in accordance with the Islamic principles. 


\section{Conclusions}

The results of the study revealed that there is an influence between the principles of Good Corporate Governance and Shariah compliance on customer trust using SPSS. Based on research conducted at the Bank Syariah Mandiri Situbondo Branch Office, it is concluded that transparency and shariah compliance have a significant positive effect on customers trust of BSM Situbondo Branch Office. While accountability, responsibility, independence and fairness do not affect the trust of customers in BSM Situbondo Brach Office.

Transparency affects customer trust because BSM has provided material and relevant information that is easily accessed and understood by customers and stakeholders. Furthermore, shariah compliance influences customer trust because BSM in its operational activities has applied sharia principles in accordance with the applicable regulations. It definitely will give confidence to customers/stakeholders that the bank chosen can be trusted in managing the funds deposited. The disclosure of information and bank management in accordance with the rules will reduce the information asymmetry and agency costs.

Accountability does not affect customer trust because customers only pay attention to the service given without considering the policies taken by Islamic banks. Responsibility does not affect customer trust due to lack of customer knowledge about the laws and regulations on Islamic banking and the lack of bank socialization to customers/stakeholders related to the form of Islamic bank concern for the community and the environment. Furthermore, independence does not affect customer trust due to the level of customer trust in the performance of Islamic banks having the authority to regulate and monitor them. Finally, fairness has no effect on customer influence. The lack of opportunity given by Islamic banks to customers or stakeholders to provide suggestion and critics and follow-up on the existence of suggestion and critics is not quickly handled. The principles that have no significant effects cannot reduce the asymmetry of information and agency costs because, in this case, the agent is not optimal to carry out Banking operational activities that cause doubt of the principal whether the banks' operational management has met the decision made by the principal or there found negligence of task.

Research conducted has weakness and limitations, including the following: There are inconsistent answers of questionnaires according to the observations of researchers, because respondents tend to be less careful about the existing statements so that there are inconsistent with the answers to the questionnaire. The study population is customers of Bank Syariah Mandiri and take a sample of 100 people. The value of $\mathrm{R}$ Square in this study is quite low which only produces $43.8 \%$, meaning that the variables (transparency, accountability, responsibility, independence fairness and shariah compliance) examined by researchers influence only $43.8 \%$ of the trust of Bank Syariah Mandiri Situbondo Branch Office customers and the rest are explained by variables outside this study.

Based on the limitations found during the study, the followings are suggestions provided by the researcher: The future researcher is expected to assist and supervise each respondent in filling out the questionnaire to answer the questions. In addition, choosing various banks will provide better understanding on the implementation of GCG and shariah compliance on other Islamic Banks. Since the value of R Square only produces $43.8 \%$, it indicates that in this study the variables of transparency, accountability, responsibility, independence, fairness and shariah compliance still have a small effect on the trust of BSM customers, therefore future researchers should use other variables for better results.

\section{References}

Ali, K., Akhtar, M. F., \& Ahmed, H. Z. (2011). Bank-specific and macroeconomic indicators of profitability-empirical evidence from the commercial banks of Pakistan. International Journal of Business and Social Science, 2(6), 235-242.

Ahokpossi, M. C. (2013). Determinants of bank interest margins in Sub-Saharan Africa (No. 13-34). 
International Monetary Fund.

Bank Indonesia. (2009) Peraturan Bank Indonesia Nomor 11/33/2009 tentang pelaksanaan Good Corporate Governance bagi Bank Umum Syariah dan Unit Usaha Syariah.

Cevik, S., \& Charap, J. (2015). The behavior of conventional and Islamic bank deposit returns in Malaysia and Turkey. International Journal of Economics and Financial Issues, 5(1), 111-124.

Donaldson, L., \& Davis, J. H. (1990). Stewardship theory or agency theory: CEO governance and shareholder returns. Australian Journal of management, 16(1), 49-64..

Donaldson, J., \& Davis, J. H. (1997). Towards a Stewardship Theory of Management, academy of Management review 1997.

Eisenhardt, K. M. (1989). Agency theory: An assessment and review. Academy of management review, 14(1), 57-74.

Faozan, A. (2014). Implementasi Shariah Governance di Bank Syariah. Jumal Ilmu Syari'ah dan Hukum Vol, 49(1)..

Ghozali, Imam. (2016). Aplikasi Multivariate dengan Program IBM SPSS. Yogyakarta: Universitas Dipenogoro.

Grassa, R. (2016). Corporate governance and credit rating in Islamic banks: does Shariah governance matters?. Journal of Management \& Governance, 20(4), 875-906.

Hamdani, M. (2016). Good Corporate Governance (Gcg) Dalam Perspektif Agency Theory. Semnas Fekon, 279-283.

Hanggraeni, D. (2015). Manajemen Resiko Perusahaan (Enterprise Risk Management) dan Good Corporate Governance. Jakarta. Universitas Indonesia. ISBN/ISSN: 9789794565551

Idris, F. F. A., Asari, H., Taufik, N. A. A., Salim, N. J., Mustaffa, R., \& Jusoff, K. (2011). Determinant of Islamic banking institutions' profitability in Malaysia. World Appl. Sci. J, 12, 01-07.

Jensen, M. C., \& Meckling, W. H. (1976). Theory of the firm: Managerial behavior, agency costs and ownership structure. Journal of financial economics, 3(4), 305-360.

Juliansyah, N. 2014. Analisis Kemiripan Karakteristik Pekerjaan Bank Dan Lembaga Keuangan. Jurnal Studia Akuntansi dan Bisnis 2 (2) 154-172.

Junusi, R. (2012). Implementasi Syariah GovernanceSerta Implikasinya Terhadap reputasi dan Kepercayaan Bank Syariah. Al-Tahrir 12 (1), 91-115.

Komite Nasional Kebijakan Corporate Governance. (2004). Pedoman Good Corporate Governance Perbankan Indonesia.

Masood, O., \& Ashraf, M. (2012). Bank-specific and macroeconomic profitability determinants of Islamic banks: The case of different countries. Qualitative Research in Financial Markets, 4(3), 255-268

Nurohmah, A. (2013). Analisis Pengaruh Prinsip-Prinsip Good Corporate Governance (GCG) Terhadap Kepercayaan Nasabah Pada Bank Muamalat Kendal (Undergraduate Thesis, IAIN Walisongo).

Punamasari, I., \& Darma S. (2015), Pengaruh Implementasi Syariah Governance Terhadap Loyalitas Nasabah. Journal of Accounting and Investment 16 (1), 12-24

Sari, I. (2010). Pengaruh Mekanisme Good Corporate Governance Terhadap Kinerja Perbankan Nasional (Studi pada Perusahaan Perbankan yang Terdaftar di Bursa Efek Indonesia Periode 20062008) (Undergraduate Thesis, Universitas Diponegoro). 
Sari, R. (2017). Shariah Enterprise Theory Sebagai Alat Analisis Pengimplemntasian Corporate Social Responsibility (Studi Kasus Pada PT. Bank BRI Syariah Cabang Malang). Universitas Islam Negeri Maula Malik Ibrabim Malang.

Shleifer, A., \& Vishny, R. W. (1999). 'A Survey of Corporate Governance', Journal of Finance, LII (2), June, 737-83. International Library Of Critical Writings In Economics, 106, 20-66.

Sudarsono, H (2017). Analisis Pengaruh Kinerja Keuangan terhadap Profitabilitas Bank Syariah di Indonesia. Economica: Jurnal Ekonomi Islam, 8 (2), 175-203.

Sugiyono. (2017). Metode Penelitian Kuantitatif, Kualitatif dan RひDD. Bandung. Alfabeta. ISSN : 18298486

Triwuyono, I. (2007). Mengangkat "sing liyan" untuk Formulasi Nilai Tambah Syariah. Simposium Nasional Akuntansi X Unhas, 26-28 Juli 2007.1-21

Ubaidillah. (2016). "Analisis Faktor-Faktor yang Mempengaruhi Bank Syariah di Indonesia”. Vol.4, No.1. ISSN 2354 - 905X. Fakultas Ekonomi dan Bisnis Islam. IAIN Purwokerto

Wahananto, Edi. (2009). Penerapan Prinsip-prinsip Good Corporate Governance Di Bank Syariah. Malang: Universitas Brawijaya

Wardayati, S. M. (2011). Implikasi Shariah Governance Terhadap Reputasi dan Kepercayaan Bank Syariah. Walisongo: Jurnal Penelitian Sosial Keagamaan, 19(1), 1-24.

Wasiuzzaman, S., \& Gunasegavan, U.N. (2013). Comparative Study Of The Performance of Islamic and Conventional Banks The Case of Malaysia. Humanomics, 29 (1), 43-60

Yuraida, S. (2016). Pengaruh Shariah Governance Terhadap Kepercayaan Nasabah Bank Syariah Dengan Reputasi Perbankan Sebagai Variabel Mediasi (Studi Kasus Di Bank Pembangunan Daerah DIY Syariah). UIN Sunan Kalijaga. 